\title{
REVITALIZATION OF THE ENVIRONMENTAL SUPERVISION POLICY ON COORDINATION AND COMMITMENT BASED COAL MINING
}

\author{
Nurul Listiyani ${ }^{1}$, Rizka Zulfikar ${ }^{2}$, Rakhmat Nopliardy ${ }^{3}$ \\ ${ }^{1}$ Faculty of Law, Universitas Islam Kalimantan Muhammad Arsyad Al Banjari \\ Jl. Adhyaksa No. 2 Kayutangi Banjarmasin, Indonesia 70123 \\ Email: nurullistiyani5@gmail.com
}

${ }^{2}$ Faculty of Economics, Universitas Islam Kalimantan Muhammad Arsyad Al Banjari Jl. Adhyaksa No. 2 Kayutangi Banjarmasin, Indonesia 70123

Email:rizkazulfikar@gmail.com

${ }^{3}$ Faculty of Law, Universitas Islam Kalimantan Muhammad Arsyad Al Banjari Jl. Adhyaksa No. 2 Kayutangi Banjarmasin, Indonesia 70123

Email: rnopliardy@yahoo.com

Submitted : 30/12/2020 Reviewed:02/03/2021 Accepted:21/03/2021

\begin{abstract}
This study was conducted to find a form of control policies on environmental management for mining of coal that regulate the coordination between stakeholders, authorities and the object of supervision, as well as a commitment to an active role between the government, business actors and the community in monitoring environmental management. The approach method in this research is socio-juridical, with qualitative and quantitative analysis methods. The results showed that both from the regulatory and implementation aspects, the coordination of the implementation of supervision had not been regulated and implemented optimally, so that it did not support the realization of an integrated environmental management supervision based on the principle of integration. Based on this, it is necessary to establish a legal system for environmental management in the form of regional regulations which contain an integrated supervisory system with a shared commitment between the leading sector
\end{abstract}

Keywords: policy; supervision; coal mining; cohesiveness; coordination

DOI : 10.32801/lamlaj.v6i1.226

\section{INTRODUCTION}

Mining has an important role in development by producing raw materials for industry, absorption of labor, as a source of foreign ex- change, and increasing local revenue. But on the other hand, mining also produces various 
adverse impacts on the environment. ${ }^{1}$ Mining is an exploitation activity of natural resources that generally has an impact on the environment in the form of decreased land productivity, increased soil density, erosion and sedimentation, land movement or landslides, disruption of flora and fauna, disruption of public health and impact on micro-climate change. Meanwhile, the post-mining impacts that occur are changes in land morphology and topography, changes in the landscape (the shape of the landscape on ex-mining land is usually irregular, causing steep holes, mounds of land used for heavy equipment piling), land becomes unproductive and prone to potential Avalanche. ${ }^{2}$

\section{Figure 1.}

Mining excavation, (personal doc.)

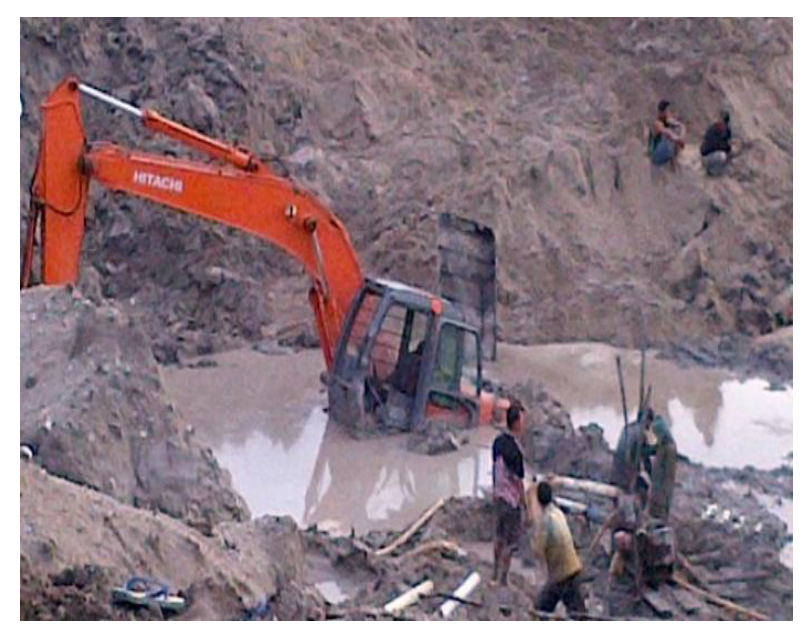

1 A'an Efendi, "Penyelesaian Kasus Pencemaran dari Aspek Hukum Lingkungan (The Settlement of Environmental Pollution from Environmental Law Aspect)," Risalah Hukum 7, no. 1 (2011): 26, https:// e-journal.fh.unmul.ac.id/index.php/risalah/article/ view/174.

2 Nurul Listiyani, Muzahid Akbar Hayat, and Subianta Mandala, "Penormaan Pengawasan Izin Lingkungan dalam pencegahan Pencemaran dan Kerusakan Lingkungan Hidup dalam Eksploitasi Sumber Daya Alam," Media Hukum 25, no. 2 (2018): 217-227, https://journal.umy.ac.id/index.php/jmh/article/ view/5420.
It is undeniable that mining activities can cause irreversible damages, because once an area is opened for mining operations, the area has the potential to be damaged forever.

In a meeting between the Ministry of Environment and Forestry (KLHK) and regional leaders held in 2019, there were discussed as many as 8,683 mining businesses that do not have permits and there are still many permit holders who do not comply with the provisions of the mandatory implementation of mining environmental management and monitoring, including reclamation and post mining. in accordance with Article 96 of Law Number 4 of 2009 concerning Mineral and Coal Mining before being revised to Law Number 3 of 2020 concerning Amendments to Law Number 4 of 2009 concerning Mineral and Coal Mining (hereinafter written the Minerba Law).

Based on the meeting, it was found that the regional government had made various efforts to optimize the environmental recovery from mining activities, both from the regulatory and management side. It is just that the division of roles in the development, supervision and restoration of the environment in activities mining still needs to be addressed.

The Minister of Home Affairs proposed the need for coordination between general supervision which is the competence of the Ministry of Home Affairs and technical supervision which is the competence of the Ministry of Energy and Mineral Resources (ESDM) and the Ministry of LHK to jointly supervise the implementation of the implementation of mining regulations by local governments, including reclamation and post-mining obligations.

From the data from the ESDM Service, there are eight districts in South Kalimantan 
that have contributed to mining voids, namely Banjar, Tapin, Regency, Balangan, Tabalong, Tanah Laut, Tanah Bumbu, and Kotabaru districts. The Head of Mineral and Coal of the Ministry of Energy and Mineral Resources of South Kalimantan, Gunawan Harjito, said that the total voids of all IUP holders in South Kalimantan were 1,579.04 hectares. The side of coordination and facilitation which tends to be passive is one of the main triggers related to environmental damage from mining activities. $^{3}$

The absence of an integrated regulation to overcome the deadlock in coordination of environmental management supervision of coal mining is the main point being studied. Where the regulation contains parameters for the fulfillment of coordination and synergy indicators between agencies as leading sectors in the supervision of environmental management, namely the Ministry of Environment and Forestry and the Ministry of Energy and Mineral Resources, at the regional level, the Environmental Service and the ESDM Service, and the fulfillment of community involvement in the mining activity stage.

Based on the description above, there are 2 (two) legal issues that have the urgency to be studied, which are :What monitoring indicators are needed in regulations governing environmental management supervision of coal mining and How the integrity of the principle of integration becomes a foothold in the regulation of environmental management monitoring.

\footnotetext{
3 Hanifah Dwi Nirwana Kepala Dinas Lingkungan Hidup Provinsi Kalimantan Selatan, Interview by, Nurul Listiyani, (09 April, 2020).
}

\section{METHOD}

The empirical legal research approach which emphasizes the aspect of Das Sollen the legal rule made by the governmental organ authorized to trace the basis of law / supervision regulation of environmental management as stated in the environmental permit, and to review it for later to be described in the form of a draft policy. The draft is then analyzed using parameters from legislation, legal theory and expert opinion (doctrine) which aims to seek and obtain answers from 2 (two) main problem formulations as described above.

The data used by researchers, which are :

1. Primary data, The data obtained from the results of field research directly from sources in the field and the implementation of focus group discussions, as well as from respondents (field research).

2. Secondary data obtained from the results of library research in which researchers collect and study regulations related to environmental law policies that researchers can describe as follows:

a) the 1945 Constitution;

b) Law number 32 of 2009 concerning Environmental Protection and Management (UUPPLH) ;

c) Law Number 23 of 2014 concerning Regional Government;

d) Law Number 3 of 2020 concerning Amendments to Law Number 4 of 2009 concerning Mineral and Coal Mining

e) Government Regulation Number 27 of 2012 concerning Environmental Permits.

Furthermore, the steps taken by researchers in data collection and analysis are as follows:

1. Preparatory and coordination meetings 
2. To collect primary data, the research team conducted direct observations at agencies competent with the implementation and issuance of policies / regulations on environmental management supervision, which are: Regional Secretariat (Sekda) South Kalimantan Province, Regional Secretariat of Tabalong Regency, South Kalimantan Province and Tanah Bumbu Environmental Service (DLH), Tabalong and Tanah Bumbu Regency DLH, South Kalimantan ProvinceOffice Energy and Mineral Resources, South Kalimantan Provincial DPRD, Tanah Bumbu Regional DPRD. Observations were also made directly at the mining company, namely PT. Adaro Indonesia. The questionnaire containing the questionnaire is also the primary data source. Furthermore, the results of primary data collection were brought into a theme discussed together in a Focus Group Discussion (FGD). FGD has a very high level of urgency to gather thoughts / input / criticism in order to get a common perception in the process of reviewing, drafting, testing and making policy documents.

3. To collect secondary data, researchers do this by systemizing written legal materials in the form of statutory regulations and re- search results, articles in journals that are related to the problems under study.

4. At the data analysis stage, the results of the FGD were gathered to be conceptualized and conducted a public test attended by relevant agencies and stakeholders.

\section{ANALYSIS AND DISCUSSION}

Environmental problems in mining in reality in Indonesia, many questions. The reason is the negative impact in the exploitation of minerals as a result of mining operations in the form of, destruction of forests, pollution of the sea, outbreak of the disease, as well as conflicts in the communities around the mine. The direct impact is ecological damage and the possibility of flooding and landslides.

South Kalimantan is one of the provinces that has the largest natural coal resources in Indonesia. When referring to the opinion that there is no mining activity that does not damage the environment. So this opinion is very relevant to the Data of the Regional Disaster Management Agency (BPBD) of South Kalimantan Province which recorded high numbers of floods and landslides in districts in South Kalimantan which have large natural resources.

Tabel 1. South Kalimantan Province Flood Recap Data for the Period of 1 January to 31 December 2019 (Data Source BPBD South Kalimantan Province)

\begin{tabular}{|c|c|c|c|c|c|c|c|c|c|c|c|c|c|}
\hline \multirow{2}{*}{ No } & \multirow{2}{*}{ KABUPATEN / KOTA } & \multicolumn{2}{|c|}{ TERDAMPAK } & \multicolumn{4}{|c|}{ KERUSAKAN PERMUKIMAN } & \multicolumn{4}{|c|}{ SARANA PRASARANA } & \multirow{2}{*}{$\begin{array}{l}\text { Frequensi } \\
\text { Kejadian }\end{array}$} & \multirow{2}{*}{$\begin{array}{c}\text { Taksiran Kerugi } \\
(\mathrm{Rp})\end{array}$} \\
\hline & & $\mathrm{KK}$ & $\mathrm{NIW} /$ & $\mathbf{R}$ & RB & $\mathbf{R}$ & RR & Jalan & Jembatan & S. Ibadah & Sekolah & & \\
\hline 1 & BARITO KUALA & 0 & 0 & 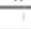 & 0 & 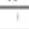 & 0 & 0 & 0 & 0 & 0 & & Rp \\
\hline 2 & BANJARMASIN & 0 & 0 & + & 0 & + & 0 & 0 & 0 & 0 & 0 & 0 & Rp \\
\hline 3 & BANJARBARU & 0 & 8 & T & 0 & + & 0 & 0 & 0 & 0 & 0 & 2 & $R_{p}$ \\
\hline 4 & BANUAR & 1 & 2 & 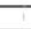 & 0 & + & 1 & 0 & 0 & 0 & 0 & 1 & $R p$ \\
\hline 5 & TAPIN & 0 & 0 & 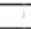 & 0 & 1 & 0 & 0 & 0 & 0 & 0 & 0 & Rp \\
\hline 6 & HULU SUNGAI SELATAN & 1 & 2 & 7 & 0 & & 0 & 0 & 0 & 0 & 0 & 2 & Rp \\
\hline 7 & HULU SUNGAI TENGAH & 0 & 0 & T & 0 & I & 0 & 0 & 0 & 0 & 0 & 0 & Rp \\
\hline 8 & HULU SUNGAI UTARA & 0 & 0 & 7 & 0 & 7 & 0 & 0 & 0 & 0 & 0 & 0 & $R_{p}$ \\
\hline 9 & BALANGAN & 8 & 24 & & 0 & & 2 & 100 & 0 & 0 & 0 & 6 & Rp \\
\hline 10 & TABALONG & 0 & 0 & 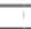 & 0 & 1 & 0 & 170 & 0 & 0 & 0 & 2 & Rp \\
\hline 11 & TANAH LAUT & 0 & 0 & 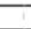 & 0 & + & 0 & 0 & 0 & 0 & 0 & 0 & Rp \\
\hline 12 & TANAH BUMBU & 0 & 0 & 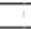 & 0 & 7 & 0 & 0 & 0 & 0 & 0 & 0 & Rp \\
\hline 13 & KOTABARU & 10 & 41 & & 0 & & 0 & 0 & 0 & 0 & 0 & 3 & Rp \\
\hline & TOTAL & 20 & 77 & 1 & 0 & & 3 & 270 & 0 & 0 & 0 & 16 & Rp \\
\hline
\end{tabular}


Tabel 2. Landslide Recap Data in South Kalimantan Province, Period 1 January to 31 December 2019 (Data Source BPBD South Kalimantan Province)

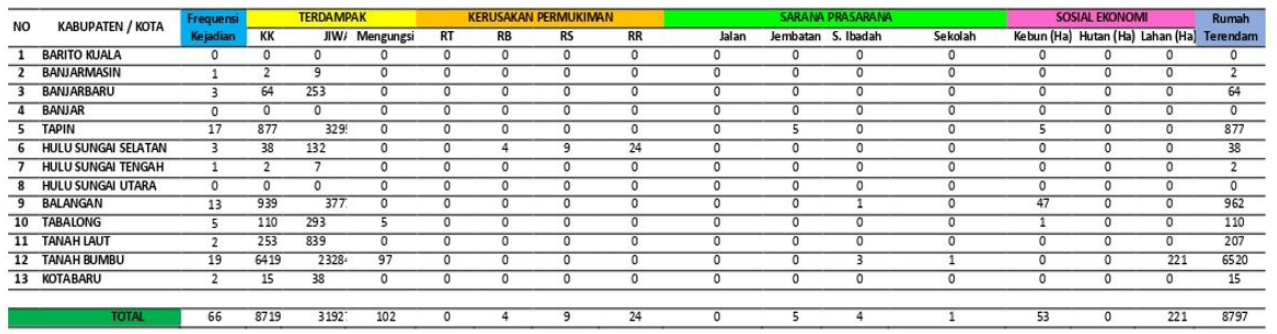

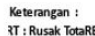

From tables 1 and 2, it can be seen that the two districts that have the largest natural resource content in South Kalimantan, which are Tanah Bumbu Regency, Balangan Regency and Tabalong Regency have the largest number of floods and landslides during the year.

The impacts arising from pollution and damage to environmental management are generally difficult, even irreversible. Therefore, the preventive function of environmental problems stemming from business activities can be realized through the form of supervision, especially supervision in the environmental aspect. The implementation of environmental supervision is a series of activities to obtain in-depth information about a business and / or activity, including in the form of activity processes, compliance with regulations and requirements and obligations contained in a permit, and evaluation of environmental management methods. ${ }^{4}$

South Kalimantan as one of the provinces that has the largest coal resources in Indonesia. It is recorded that the area of the coal mining business license area is $5,137,875.22$ hectares consisting of PKP2B, KK and IUP, with

\footnotetext{
${ }^{4}$ Nurul Listiyani, Asas Keterpaduan Sebagai Dasar Konsep Integrasi Pengawasan Terhadap Pertambangan Mineral Dan Batubara, (Yogyakarta: Penakita, 2019), 28.
}

details of the licenses registered in the data of the Office of Energy, Mineral Resources of South Kalimantan Province, which are:

a. Coal Mining Work Agreement (PKP2B) totaling 19 fruit

b. COW amounted to 2 pieces

c. Usah Mining Permit (IUP) amounted to 373 pieces

From the perspective of normative law, can be observed inconsistencies norm setting vertical and horizontal natural resource management at the level of legislation, namely:

1) Incompatibility (desynchronization) norm setting between law -The sectoral legislation that regulates the management of natural resources with the 1945 Constitution of the Republic of Indonesia (UUD NRI 1945).

2) Disharmony is the regulation of norms that govern the management of natural resources.

From the initial study conducted by researchers on the Mineral and Coal Mining Law and UUPPLH, the discrepancies and disharmony are shown in one of the content materials that regulate the substance of environmental supervision.

The main effort that must be made in environmental management is the prevention of pollution and environmental damage, in which Article 1 number (2) UUPPLH states 
that one of the preventive efforts is to carry out systematic and integrated supervision.

Edith Brown Weiss stated that prevention and mitigation are two tools used to protect the environment. The principle of prevention aims to prevent specific damage that arises, for example from changes in the environment, damage to people or the environment, or a burden that exceeds the capacity of the environment to accept it. The principle of prevention is a fundamental principle in environmental protection efforts, because with a preventive approach, parties are required to carry out "due diligence". In other words, take appropriate action and in good faith and regulate public or private activities within its jurisdiction or control possible hazards to the environment. Environmental law enforcement efforts should only be utilized when efforts to prevent environmental pollution have not been effective. ${ }^{5}$

In a research conducted by the research team who received the 2019/2020 Ristekdikti grant, based on the qualitative data collected at the stage focus group discussion attended by stakeholders (Provincial and Regency Regional People's Representative Council, Secretariat Regional (Setda) of South Kalimantan Province, Environmental Service, Energy and Mineral Resources Service, District Government, mining actors, non-governmental organizations, academics and research partners), found important points that have the urgency of being regulated in the content of the content of life management supervision of coal mining, namely the need for coordination in supervision since the planning stage, commit-

${ }^{5}$ Efendi, "Penyelesaian Kasus Pencemaran dari Aspek Hukum Lingkungan (The Settlement of Environmental Pollution from Environmental Law Aspect)." 45. ment between leading sector supervision and a clear division of supervisory authority.

\section{Coordination of Supervision}

Protection and management of the environment is carried out comprehensively, including planning, utilization, control, maintenance, supervision and law enforcement. This affirmation is based on the consideration that in environmental matters a comprehensive approach must be used, starting from upstream to downstream, namely from planning to law enforcement where the problems at each stage are seen as interrelated and contribute to environmental problems. Therefore, at each of these stages several instruments can be used, which are at the planning stage the introduction of an environmental inventory, distribution of ecoregion areas, to environmental protection and management plans which must be integrated into long and medium term development plans, both at the level. national and regional. Planning is absolutely necessary to initiate the implementation of supervision in order to realize the legal will containing orders and prohibitions in the mining sector.

Mining business in the form of its implementation technically cannot be separated from other government institutions / agencies in a cross-sectoral manner. This implies that the overall implementation of the mining business should always involve cross-sectoral government agencies / agencies for the sustainability of these activities, particularly in relation to performance related to environmental management monitoring. The expectation for the involvement of this agency is intended as a realization of the issuance of IUP, both Exploration IUP and Production Operation IUP, which are instruments of law enforcement in mining areas. Therefore, ideally 
environment-friendly mining management is expected to be realized if there is a synergistic working relationship between agencies in the form of coordination.

However, this has not yet been clearly realized in the field between sectoral institutions. Empirical facts as an example found in Tabalong Regency, there is an IUP for coal mining activities that has been issued a permit, even though the company that owns the IUP has not fulfilled its obligation to submit periodic RKL-RPL reports every 6 months to the Environmental Service since holding the environmental permit. so there is a need for good coordination and communication between sectoral agencies in issuing mining business permits. Reality like this is one of the obstacles in making supervision an instrument of law enforcement, because it does not reflect integration and is still sectoral and there is no coordination and communication between agencies with one another. ${ }^{6}$

Coordination, in essence, is an act of cooperation that supports each other to obtain harmonious information which in turn will result in good cooperation between all parties. Coordination is very much needed in relation to the mining business, because in its implementation it is related to the requirements of various forms of licensing which are not only the authority of technical agencies, in this case the ESDM Service, but are related to other sectoral agencies. This linkage appears in several ways regarding licensing. For example, related to environmental permits that involve other agencies, the Service Environmental. Therefore we need legal norms that explicitly regulate. At the operational stage, it

\footnotetext{
${ }^{6}$ N. Zahriati, "Koordinasi dan Komitmen Dalam Pengawasan", Interview by, Nurul Listiyani (September, 2020).
}

is necessary to have the same understanding from various parties, especially law enforcers in the field related to the matter intended. Coordination is absolutely necessary for synergy and especially in addressing problems related to the environment.

Coordination from the initial planning stage is needed to generate useful input and perceptions for the community concerned (public interest) in order to improve quality in conjunction with environmental decision making. Therefore, ideally, a coordination system should be formulated from the start. ${ }^{7}$

Given the complexity of environmental management and the lively mining business problems carried out by the person in charge of businesses and / or activities mining, it has an impact on environmental damage. Local Governments can carry out the Authority and Policies for the prevention and prevention of mining consequences with the principle of sustainable development. Legal efforts taken to resolve environmental management problems as well as law enforcement and strict application of sanctions in the mining sector by coordinating the prevention and countermeasures of coal mining are needed at the central and regional levels. ${ }^{8}$

With various Laws of the Republic of Indonesia from all aspects both the Mineral and Coal Mining Law and UUPPLH which has been in effect can solve a variety of serious problems, ranging from lawlessness and uncontrollable environmental damage.

Taking into account some of the above, it is necessary to coordinate between the Environ-

\footnotetext{
Fenty Puluhulawa, "Substansi Hukum Tentang Pengawasan Izin Pada Usaha Pertambangan," Pelangi Ilmu 3, no. 4 (2010): 148.
8 A. Hanafi, "Koordinasi mutlak diperlukan dalam pengawasan" interview by Nurul Listiyani (September, 2020).


mental Service and the ESDM Office in terms of environmental monitoring in terms of:

1. Coordination to ensure that the RKAB and RKTTL are issued by ESDM before the UKL-UPL amdal document, thepermit environmental exists and has been issued before allowed exploitation is and obliged to be informed to DLH Province and District / City.

2. Coordination and information related to reclamation guarantees should be coordinated with DLH as the supervisory agency for reclamation and revegetation both at Provincial and District / City levels.

3. Post-mining coordination, ensure that environmental management studies must be made by the mining company, before 2 years of operation, to ensure the benefits of post-mining land in the District / City.

Furthermore, if there are problems with environmental cases technically it is necessary to coordinate with regard to:

1. Implementation of pollution prevention and cessation of sources of pollution against the corporation as the person in charge of the business and / or activity.

2. Implementation of restoration of pollution (cleaning, remediation, rehabilitation and restoration) of contaminated sources.

3. Development of information systems and conditions for potential impacts.

4. Implementation of protection of natural resources and supervision of natural resources and their arrangement.

\section{Commitment}

One principle in the management of natural resources and the environment, which is intended to prevent pollution and / or destruction of natural resources and the environment, is the precautionary principle. The philo- sophical meaning of the precautionary principle is natural resources as a living system of living things or an ecological system that gives life to living things, especially humans. If one ecological sub-system is polluted or damaged, it will affect other sub-systems and disturb the ecological balance which in the end can negatively affect and threaten the lives of living things, especially humans. Therefore, humans must be careful in treating their environment and the natural resources that give life to humans. ${ }^{9}$ The environment must be treated as if it was treating itself by humans. It is better to prevent early pollution and / or damage to natural resources and the environment prevent than to and recover after it occurs. In the General Elucidation of Law Number 32 of 2009 concerning Environmental Protection and Management, it is stated that preventive law enforcement as an effort to prevent environmental pollution and damage can be carried out through instruments monitoring and licensing.

Supervision planning in sectoral agencies related to environmental management supervision is carried out individually by each ESDM Agency and the Environmental Service Agency, ideally the supervision planning is carried out in an integrated manner so that in essence it plays an important role in and determines the optimal implementation of supervision.

Therefore, through integrated supervision planning, commitment mutual and common perception are needed, so that it is hoped that the entire series of supervision can be carried out according to the target set in an integrated manner, so that administrative law enforcement efforts can be carried out. Through inte-

\footnotetext{
9 A. Sonny Keraf, Etika Lingkungan. (Jakarta: PT. Kompas Media Nusantara, 2010), 42
} 
grated supervision, it is hoped that the implementation will not deviate from the essence and purpose of supervision.

According to Abrar Saleng, the essence of supervision from the perspective of administrative law is the control of an activity carried out by a government agency / agency entrusted with the task of being a supervisor by statutory regulations. ${ }^{10}$ Supervision is the duty of government institutions, so it is closely related to administrative law.

The close link between environmental regulations in the mining sector issued by the Ministry of Energy and Mineral Resources and environmental regulations issued by the Ministry of the Environment should never conflict and work in harmony with each other. The harmony between the core and the spirit contained in the clauses in each mining sector and the environment is not always a harmonious journey in practice. One example that could occur is for example the enforcement of environmental laws in the form of sanctions administrative in the form of government coercion to stop production operations issued by the Environmental Service against mining business actors who do not comply with the compliance value stipulated in regulations, sometimes ignored by the Energy and Resources Office. Mineral (mining) while still guaranteeing the company concerned to continue operating as usual. ${ }^{11}$

Another example, when the Environmental Agency directs mining business actors to immediately carry out rehabilitation efforts (reclamation and revegetation) of a land that is disturbed and becomes a source of pollu-

\footnotetext{
${ }^{10}$ Abrar Saleng, Hukum Pertambangan. (Yogyakarta: UII Press, 2004).

${ }^{11}$ Saleh, "Ketidakharmonisan Regulasi" Interview by Nurul Listiyani, (DLH Tanah Bumbu, Oktober 2020).
}

tion, it turns out that the RKAB document that has been approved by the Department of Energy and Mineral Resources of the area / location is not included. in the reclamation and revegetation plan.

The cause of this situation is due to the existence of sectoral egos both in official and personal / individual supervisors (knowledge and experience factors) who hold decisions in each sector because they feel they are not in line with their respective desires. ${ }^{12}$

Furthermore, the community as part of the environment which is one of the components affected by mining activities, has rights and obligations to environment a good and healthy, and has the obligation to protect and protect the environment. Community participation in environmental protection and management has been regulated in the UUPPLH.

The principle of public participation that is true (genuine public participation) to give greater opportunities to the public and all stakeholders to take an active part, from the stage of identification and inventory, planning, implementation, monitoring and supervision of policy implementation of natural resource management .

Furthermore, in the sectoral law, in the explanation of the Mineral and Coal Mining Law it is stated that in the framework of creating sustainable development, mining business activities must be carried out by taking into account the principles of the environment, transparency and community participation. This provision clearly shows that the role of the community must be involved in every

\footnotetext{
${ }^{12}$ Syahrozat, "Indikator penyebab belum maksimalnya pengawasan" Interview by Nurul Listiyani (DLH Tanah Bumbu, Oktober 2020).
} 
mining business activity. ${ }^{13}$ One of them is the provision in Article 21 of the Mineral and Coal Mining Law which states that the regent / mayor is obliged to make public announcements regarding the plan for Community Mining Areas. Community participation in involvement in mining business activities because mining activities are a major activity in the community, where of course this activity will interact with the local community where the mining location is located. Community involvement is very important because there are many aspects that need to be considered in mining activities, from economic equality to considering environmental sustainability and the impact of these activities on the local community where mining business activities are carried out. ${ }^{14}$

\section{Integrated Regional Policy Based on the Principle of Integrity}

Article 18 paragraph (6) of the 1945 Constitution states that regional governments have the right to stipulate regional regulations (Perda) and other regulations to implement regional autonomy and assistance tasks. In this regard, the national legal system gives attributive authority to the regions to stipulate regional regulations and other regional regulations, and the regional regulations are expected to synergistically support government programs in the regions. ${ }^{15}$

\footnotetext{
${ }^{13}$ Ade Maman Suherman, Aspek Hukum dalam Ekonomi Global. (Jakarta: Ghalia Indonesia, 2005), 12.

${ }^{14}$ Maria SW Sumardjono et al., Pengaturan Sumber Daya Alam Di Indonesia Antara Yang Tersurat Dan Tersirat Kajian Kritis Undang-Undang Terkait Penataan Ruang Dan Sumber Daya Alam. (Yogyakarta: Gadjah Mada University Press, 2011), 206.

${ }^{15}$ Hamidi Jazim, and Lutfi Mustafa, "Eksistensi Komisi Ombudsman Nasional dalam Mewujudkan Good
}

Perda as well as other statutory regulations (PUU) have a function to realize legal certainty (rechtszekerheid, legal certainty). For the functioning of legal certainty, certain conditions must be met, including consistency in the formulation, where in the same PUU, a systematic relationship must be maintained between its principles, standardized structure and language, and a harmonious relationship between various laws and regulations. Other functions of the Perda include, among others, a policy instrument in the regions to implement regional autonomy and assistance tasks as mandated in the 1945 Constitution and the Regional Government Law, however, these Perda are basically the implementing regulations of a higher PUU. Additionally regulation may serve as instrument a policy for the container specificity and diversity of the area as well as the voice of the people in the region, but in its regulation within the remit of the Republic of Indonesia based on Pancasila and the 1945 Constitution ${ }^{16}$

In its function as instrument a policy for the container specificity and diversity of the area and channeling the aspirations of the community in the region, so as an area rich in natural resources, the regional government is essentially more proactive in making regulations related to environmental-oriented natural resource management. The issue of environmental problems as a result of mining activities does not only occur in Indonesia, but

Governance," Hukum Varia Peradilan 24, no.281 (2009): 47.

${ }^{16}$ Kartono Kartowiyono, “Analisa Konflik Hukum Kewenangan Pengawasan Kegiatan Pertambangan Pasca Berlakunya Undang-Undang Pemerintahan Daerah Tahun 2014," Bina Hukum Lingkungan 2, no.1 (2017): 30-39, http://bhl-jurnal.or.id/index.php/ bhl/article/view/bhl.v2n1.3 
has become a serious problem globally. ${ }^{17}$

Considering that a good and healthy environment is the main basic human need, therefore its fulfillment is part of human rights, so that normatively it becomes the responsibility of the state which has the mandate to carry out the process of fulfilling it constitutionally. Wotldview are then legitimized by the Constitution NRI 1945, which expressly govern the obligations of the state (state obligation) to advance(topromote), shield (to protect) and meet (to fulfil) constitutional rights of citizens to meet their basic needs. ${ }^{18}$

The principle of integration in environmental protection and management has been mentioned in the Rio Declaration, which explicitly states the existence of a Principle of Integration which states "environmental protection shall constitute an integral part of the development process and cannot be considered in isolation from it". Cohesiveness relates to planning, implementation and supervision. Integrity also includes spatial planning, protection of environmental resources, and integrated management at government levels, the central and regional levels.

Conceptually, the notion of integration clearly shows the scope of the environment that is integral (one unit / integrated). The concept then has consequences on the scope of environmental management, including the scope of the environmental management

\footnotetext{
${ }^{17}$ The Hon, and Justice Brian J Preston, "Environmental Justice and Land Use Conflict: The Governance of Mineral and Gas Resource Development," Journal of Energy \& Natural Resources Law 36, no.3 (2018): 364-369, https://www.tandfonline.com/doi/abs/10.10 80/02646811.2017.1401763

${ }^{18}$ Rachmad Safa'at, Rekonstruksi Politik Hukum Pangan, dari Ketahanan Pangan ke Kedaulatan Pangan, Cetakan I (Malang: UB. Press, 2013).
}

monitoring system. ${ }^{19}$

In the explanation of article by article UUPPLH it is formulated that what is meant by the principle of integration is that "environmental protection and management is carried out by combining various elements or synergizing various related components". Furthermore, in the General Explanation of the UUPPLH it also implicitly states the principle of integration of the sentence: it is necessary to develop a clear, firm, and comprehensive legal system for environmental protection and management to ensure legal certainty as a basis for the protection and management of natural resources and other development activities.

On the basis of these concepts, it is necessary at the regional level to formulate an integrated policy as a positive environmental law that is comprehensive and integrated for the entire environmental protection and management system in South Kalimantan.

In the environmental sector, as the mandate contained in the provisions of Article 10 paragraph (3) letter $b$ of Law Number 32 of 2009 concerning Environmental Protection and Management, and the provisions of Article 12 paragraph (2) letter e and attachment letter K number 1 of the Law -Law No. 23/2014 on Regional Government, South Kalimantan already has regulations, namely Regional Regulation No. 2 of 2017 concerning Environmental Protection and Management Plans. It's just that the content of the Perda does not completely contain preventive efforts to prevent damage and pollution to the environment.

Ideally, with the principle of integration, a

\footnotetext{
19 Philipus M.Hadjon, "Penegakan Hukum Administrasi dalam Pengelolaan Lingkungan Hidup," Jurnal Ius Quia Iustum 2, no.4 (1995): 45-53, https://journal.uii. ac.id/IUSTUM/article/view/5022.
} 
legal system is created in the form of regional regulations that regulate environmental legal aspects of the sectors, one of which regulates the content of environmental management supervision.

Mandate between Law no. 4 of 2009 with its amendments and Law no. 32 of 2009 concerning PPLH and Law no. 23/2014 can be a strong foundation for initiating a collaborative monitoring strategy with various parties including district / city governments, village governments, civil society organizations, and community groups directly affected by mining activities.

This disharmony of practice is certainly a material for future evaluation for regulators and executors both in the mining and environmental sectors because the spirit and enthusiasm of each regulation certainly has a good aim, which is achieving obedient and environmentally friendly mining businesses and fulfilling good mining practices in it. there are aspects of prioritizing environmental compliance.

The effectiveness of the results of supervision can run well if the results of the recommendations for supervision are synergistic between institutions, the results of supervision are collaborated with sanctions and operational permits, the results of supervision activities by the Environmental Service have an influence on the Department of Energy and Mineral Resources and vice versa so that they can mutually strengthen one each other.

With the existence of integrated and synergic and well-coordinated supervision among related sector agencies in South Kalimantan, we hope that in the supervision of coal mining activities, the resulting indicators of success in Environmental Management Supervision include:
1. The increasing number of business actors who are obedient to environmental management in accordance with the issued environmental permits

2. The increasing number of business actors and / or (mining) activities that comply and can apply environmental documents

3. Increased commitment of stakeholders in environmental preservation efforts

4. Increased awareness of business actors / activities to comply with environmental laws and regulations.

\section{CONCLUSION}

The reconstruction of the environmental supervision policy on coal mining is carried out by incorporating content material on supervision whose substance regulates the existence of a clear and firm coordination line between related agencies, as well as substances that regulate commitments between related stakeholders in environmental supervision of coal mining.

Coordination becomes the point of resolution for the synchronization and disharmony of supervisory arrangements. A cross-sectoral supervisory approach, by placing mining supervision as an integral part of environmental protection and management. Meanwhile, collaboration and commitment between local governments and resources outside local government institutions such as mining entrepreneurs, civil society groups and affected communities aims to strengthen participation in supervision.

\section{BIBLIOGRAPHY}

\section{Books}

Keraf, A. Sonny. Etika Lingkungan. Jakarta:

PT. Kompas Media Nusantara, 2010.

Listiyani, Nurul. Asas Keterpaduan Sebagai 
Dasar Konsep Integrasi Pengawasan Terhadap Pertambangan Mineral Dan Batubara. Yogyakarta: Penakita, 2019.

Safa'at, Rachmad. Rekonstruksi Politik Hukum Pangan, dari Ketahanan Pangan ke Kedaulatan Pangan. Cetakan I. Malang: UB. Press, 2013.

Saleng, Abrar. Hukum Pertambangan. Yogyakarta: UII Press, 2004.

Suherman, Ade Maman. Aspek Hukum dalam Ekonomi Global. Jakarta: Ghalia Indonesia, 2005.

Sumardjono, Maria SW, Nurhasan Ismail, Ernan Rustiadi, and Abdullah Aman Damai. Pengaturan Sumber Daya Alam Di Indonesia Antara Yang Tersurat Dan Tersirat Kajian Kritis Undang-Undang Terkait Penataan Ruang Dan Sumber Daya Alam. Yogyakarta: Gadjah Mada University Press, 2011.

\section{Journal}

Efendi, A'an. "Penyelesaian Kasus Pencemaran dari Aspek Hukum Lingkungan (The Settlement of Environmental Pollution from Environmental Law Aspect)." Risalah Hukum 7, no 1 (2011): 26, https://ejournal.fh.unmul.ac.id/index.php/risalah/ article/view/174.

Hadjon, Philipus M. "Penegakan Hukum Administrasi dalam Pengelolaan Lingkungan Hidup." Jurnal Ius Quia Iustum 2, no.4 (1995): 45-53, https://journal.uii.ac.id/ IUSTUM/article/view/5022.

Hon, The, and Justice Brian J Preston. "Environmental Justice and Land Use Conflict: The Governance of Mineral and Gas Resource Development." Journal of Energy \& Natural Resources Law 36, no.3 (2018): 364-369, https://www.tandfonline. com/doi/abs/10.1080/02646811.2017.140 1763.
Listiyani, Nurul, Muzahid Akbar Hayat, and Subianta Mandala. "Penormaan Pengawasan Izin Lingkungan dalam pencegahan Pencemaran dan Kerusakan Lingkungan Hidup dalam Eksploitasi Sumber Daya Alam." Media Hukum 25, no. 2 (2018): 217-227, https://journal.umy.ac.id/index. $\mathrm{php} / \mathrm{jmh} / \mathrm{article} / \mathrm{view} / 5420$.

Jazim, Hamidi, and Lutfi Mustafa. "Eksistensi Komisi Ombudsman Nasional dalam Mewujudkan Good Governance." Hukum Varia Peradilan 24, no.281 (2009): 47.

Kartowiyono, Kartono. "Analisa Konflik Hukum Kewenangan Pengawasan Kegiatan Pertambangan Pasca Berlakunya Undang-Undang Pemerintahan Daerah Tahun 2014." Bina Hukum Lingkungan 2, no.1 (2017): 30-39, http://bhl-jurnal.or.id/ index.php/bhl/article/view/bhl.v2n1.3

Puluhulawa, Fenty. "Substansi Hukum Tentang Pengawasan Izin Pada Usaha Pertambangan.” Pelangi Ilmu 3, no. 4 (2010): 148.

\section{Interview}

Hanafi, A. "Koordinasi mutlak diperlukan dalam pengawasan." Interview by Nurul Listiyani, September 2020.

Saleh.

"Ketidakharmonisan Regulasi.'Interview by Nurul Listiyani, DLH Tanah Bumbu, Oktober 2020.

Zahriati, N. "Koordinasi dan Komitmen Dalam Pengawasan" Interview by. Nurul Listiyani, 2020.

Nirwana, Hanifah Dwi. Wawancara Kepala Dinas Lingkungan Hidup Provinsi Kalimantan Selatan, Banjarbaru. April 2020.

Syahrozat. "Indikator penyebab belum maksimalnya pengawasan" Interview by $\mathrm{Nu}-$ rul Listiyani DLH Tanah Bumbu, Oktober 2020. 


\section{Law and Regulation}

UUPPLH. (2009). Law Number 32 of 2009 concerning Environmental Protection and Management Law 